\title{
Food and ecology or how dietary alterations can affect an aquatic ecosystem
}

\author{
Lambros Tsounis $^{1 *} \mathbb{D}$, Katerina lliadi ${ }^{1}$ and George Kehayias ${ }^{2}$
}

\begin{abstract}
Fishing ensures necessary food for humans and is inextricably linked with the environment because coastal communities developed special fishing procedures to achieve better exploitation of the aquatic resources. Lake Trichonis, Greece's largest natural lake, is a freshwater ecosystem in which a marine species (Atherina boyeri) has entered and dominate the ichthyofauna. This species is exploited by purse seine fishing with the use of light, and previous studies revealed that the fishing lights create a particular food chain reaction, which promotes predation among the attracted fish species, one of which is Scardinius acarnanicus that preys upon A. boyeri. The purse seine fishers typically return to the lake alive S. acarnanicus, due to its low market demand, although it is the main predator of their catch. This custom, apart from causing income losses, promotes instability in the fish populations, while eventually altered the foraging behaviour of $S$. acarnanicus and made it a fish-predator instead of a typical omnivorous species. Based on data from official fish landing recordings, interviews with local fishers, and responses to questionnaires completed by residents of villages around Lake Trichonis, the present study investigates how changes in the dietary habits of the lakeside communities over time have led to the low market demand for S. acarnanicus. The present findings revealed an interesting relation between the dietary preferences of the local population and their ecological consequences for the fish community of this lake. This will eventually lead to the increase in the top predator (S. acarnanicus) and an inevitable decrease in the main catch (A. boyeri), affecting not only the ecological status of the lake, but also the socioeconomic characteristics of the human populations in this area. From another perspective, the results demonstrate a paradigm of adapted evolution by a wild fish under the pressure of human activities.
\end{abstract}

Keywords: Ethnoichthyology, Human diet, Fish consumption, Predation, Purse seine

\section{Introduction}

Civilization began when humans first learned to use fire and other tools to modify their surrounding natural environment. Fishing, a practice older than agriculture, is a method that seems to have evolved along with humans. Evidence supports that it was practiced long before the arrival of Homo sapiens and possibly represents the oldest economic activity in human history [6, 21, 23]. The practice was particularly important since it ensured necessary food, while also being inextricably linked with the

\footnotetext{
*Correspondence: Itsounis@upatras.gr

${ }^{1}$ Department of Environmental Engineering, University of Patras, Agrinio, Greece
}

Full list of author information is available at the end of the article environment because special fishing procedures were developed based on the aquatic ecosystem.

As human civilization has evolved, diets have shifted from being high in fruits, vegetables, lean meats, and seafood to being dominated by processed foods high in sodium and hydrogenated fats and low in fibre [8]. These dietary changes affect the environment, having the power to change the natural stability of an ecosystem or even the ecosphere. For example, global livestock production is responsible for approximately $12 \%$ of the global greenhouse gas emissions that are accelerating worldwide climate change [28].

However, the connection between the human diet and the environment can also have beneficial effects on 
the ecosystem. For example, human consumption has served to control invasive species such as nutria (Myocastor coypus) [20], and considerable effort has gone into assessing the potential food use of invasive fish, such as the Asian carp (Hypophthalmichthys molitrix and Hypophthalmichthys nobilis) and the lionfish (Pterois spp.) $[1,17,26]$. Given the above, it would be interesting to see how a shift in the human diet could affect the surrounding ecosystem on a small scale, such as for a lake.

Lake Trichonis, Greece's largest natural lake, represents a typical example of a freshwater ecosystem that has been exploited by humans owing to a rich supply of fish. Situated in the western part of the country, it is part of the Natura 2000 network of protected areas. The lake is a deep $(57 \mathrm{~m})$ warm monomictic lake with oligotrophic to mesotrophic characteristics $[2,11]$, and it is one of the most important lakes of Greece in terms of freshwater fish fauna. Twenty species of fish are present in the lake, with many of them being endemic to the area [4]. Among these species, big-scale sand smelt (Atherina boyeri) has historically entered the lake via rivers and canals and is the dominant fish species, as well as the main source of fishing revenues [16]. Other fish from the lake are also marketable species and are used as food almost exclusively by the people living in lakeside communities. These communities include 23 villages and have a total population of about 20,000 residents.

The commercial fishing of $A$. boyeri in Lake Trichonis uses the purse seine fishing method, mainly during night hours and with the use of light from lamps mounted on small floating rafts. Recent studies have shown that these fishing lights create a particular food-chain interaction. This interaction starts with the phototactic arrival of zooplankton, which constitutes prey for the fish larvae of several species. Endemic Economidichthys trichonis is among these species and is in turn prey for A. boyeri [1214]. The latter species is heavily predated by Scardinius acarnanicus, which arrives in the area after a few hours [25].

A recent study by Tsounis and Kehayias [25] showed that $S$. acarnanicus is the top predator in this particular food chain and approaches the fishing lights to prey on $A$. boyeri, instead of feeding on aquatic vegetation as it was found to do in the past [7]. In the past few decades, fishers have customarily returned $S$. acarnanicus from their catch back into the lake alive. Aside from having a direct financial impact for the fishers, this practice creates an indirect problem as they are returning the predator of their target catch to the lake. Over time, the custom is expected to gradually increase the $S$. acarnanicus population (predator) against the population of $A$. boyeri (prey) and thus create an ecosystem imbalance.
The reason why $S$. acarnanicus is returned to the lake alive seems to originate from its low demand in the local market. This low demand could reflect a shift in the dietary habits of the lakeside population, which includes the main consumers of fish from the lake. In the present study, we investigate (1) a possible change over time in the dietary habits of the lakeside communities, (2) how this change affects the local fishers and the overall fisheries management of the lake, and (3) the potential ecological impacts of this dietary alteration on the fish fauna of Lake Trichonis. We anticipate that the combination of these factors will reveal possible relationships between the dietary habits of a human population and the ecological balance of a nearby aquatic ecosystem.

\section{Materials and methods}

The study was conducted in Lake Trichonis from February 2019 until February 2020, and it was based on three sources of information: fisheries data, interviews with local fishers, and questionnaire responses by the local population.

\section{Fisheries data}

Data of the official landing data collections were retrieved from the archives of the Department of Fisheries of the regional unit.

\section{Interviews with local fishers}

Interviews with 11 local fishers were conducted with the aim of investigating possible shifts of the fishing habits of the area. Interviewees included the three fishers who had the necessary permissions from the Department of Fisheries for commercial purse seine fishing of $A$. boyeri in Lake Trichonis and eight fishers that fish avocational in the lake for many years. In these interviews, the fishers were asked about the following:

- The landings of A. boyeri and S. acarnanicus in the present and the past

- Whether they are currently selling S. acarnanicus, and what its price is in the market

- When the demand for fish from the lake began to decline

- How the fishes were distributed in the market in the past and how they currently are

- Ways of cooking of S. acarnanicus

- Whether they would be willing to fish S. acarnanicus instead of throwing it back into the lake, if the demand for processing S. acarnanicus arise 


\section{Responses from the lakeside population}

A questionnaire administered to the population living in villages around Lake Trichonis was used to investigate aspects of local diets with regard to lake fishes. The questionnaire was designed to be as simple as possible, with all questions on one page, to be more approachable. Each questionnaire had two parts. The first part requested information about the gender, age, and the residence village of the respondent. The second part included the following questions about dietary habits:

1. Do you consume fish from Lake Trichonis?

2. If yes, which species?

3. How often do you consume fish from the lake?

4. How often do you consume fish in general?

5. If you don't consume fish from Lake Trichonis, what are the reasons for that?

6. In the past, did your parents and grandparents consume more fish from Lake Trichonis?

7. If yes, which species?

8. During those years, how often was the family consuming fish from the lake?

The first five questions were aimed to obtain the current opinion of the residents about their preferences for the lake's fishes and information about the frequency of consumption. The last three questions were intended to reveal possible alterations in the dietary preferences and frequencies. A total of 522 questionnaires were distributed to students in the fifth and sixth grades of the elementary school, with special permission of the Directorate of Primary Education of the district, with specific directions that the questionnaires be answered by parents and guardians and not the students themselves. This method was selected instead of telephone interviews to increase the number of answers and to ensure that responses were from families residing in the lakeside villages. The villages where questionnaires were distributed included Panetolio, Kenourgio, Paravola, Pandanasa, Zevgaraki, Papadates, Mataraga, Grammatikou, Gavalou, and Kato Makrinou (Fig. 1). Statistical significance of the answers was tested using the Chi-square test, performed in IBM SPSS Statistics. This test was used to investigate possible differences between genders concerning the consumption of fish from the lake, the age of the participants and the frequency of lake fish consumption, and finally the age of the participants and the opinions about the frequency of fish consumption in the past.

\section{Results}

Fisheries data

Data from the archives of the Department of Fisheries provided the landings of $A$. boyeri for the period 2012-2020. In 2012, the landings of $A$. boyeri reached

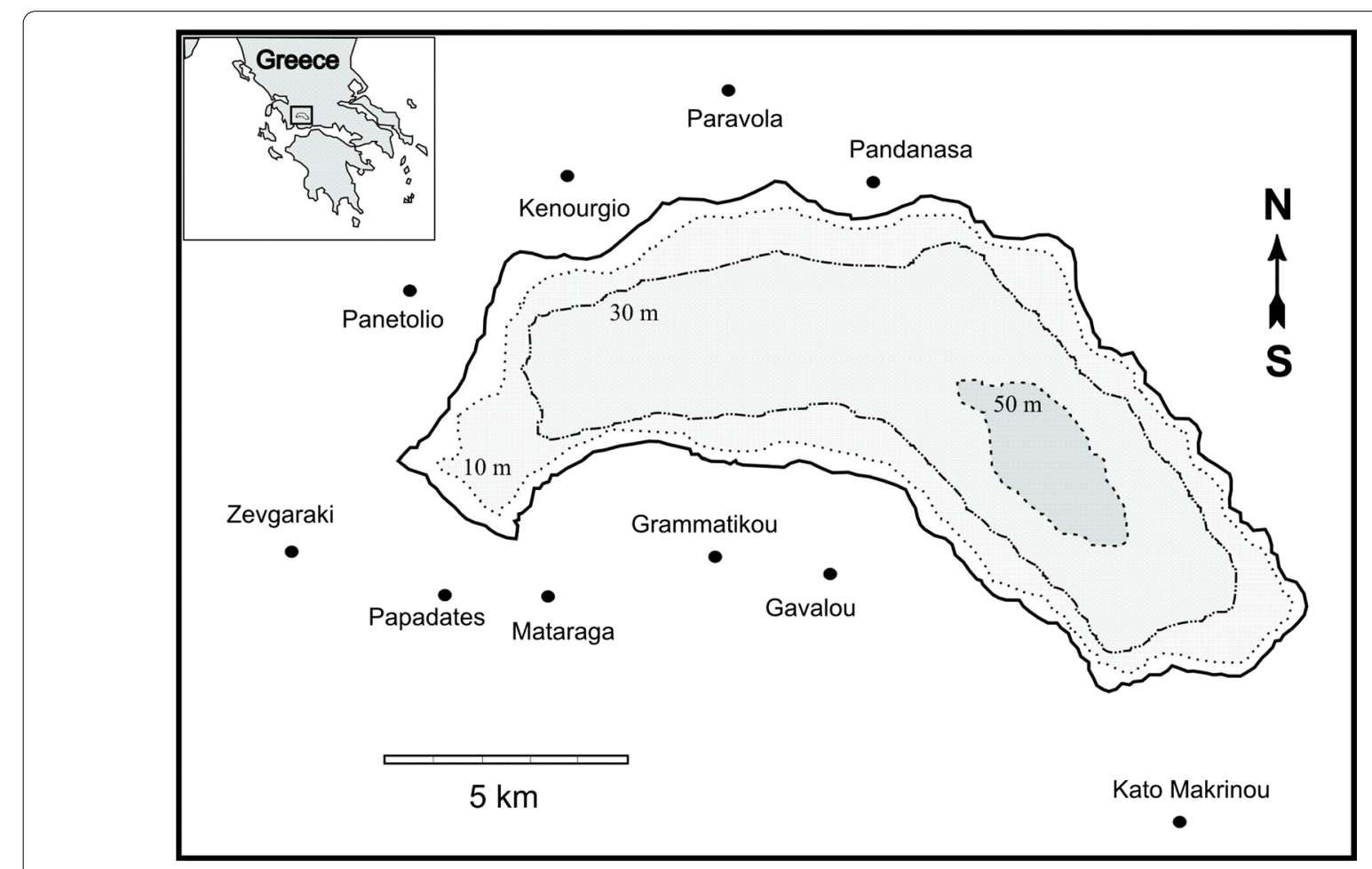

Fig. 1 Geographic location of Lake Trichonis and of the villages where the questionnaires were distributed 
133,106 kg (Fig. 2). Afterwards, landings generally decreased, with only some occasional peaks, such as in 2014 or in 2017. Nevertheless, landings did not exceed the amount in 2012, and the smallest quantity occurred in 2020 , reaching $57,564 \mathrm{~kg}$.

\section{Interviews with local fishers}

All the fishers conducting commercial purse seine fishing of $A$. boyeri reported that they usually catch and return alive large quantities of various fishes, mainly S. acarnanicus, to the lake. The discharges for this species were estimated to be between $500 \mathrm{~kg}$ and up to 2-3 tons per night depending on the season. The fishers also pointed out that the quantities of $S$. acarnanicus in catches have increased significantly compared with past catches, whereas those of $A$. boyeri have decreased considerably. Moreover, they noted that the behaviour of $S$. acarnanicus has changed during recent decades. In the past, catching this fish required absolute silence on board the fishing boat because the slightest sound frightened the school, which would then swarm away. Now, large schools of S. acarnanicus are created when the engines of fishing boats are started, and the fish follow the boats to take advantage of any fish discharge in the lake.

All the fishers agreed that from the 1980s onward, a large decrease occurred in the demand for fishes from the lake and subsequently for S. acarnanicus. Thus, their custom of returning it to the lake alive arose owing to the low demand for this fish in the local market, which leads to a price of about 3 euros $/ \mathrm{kg}$.

In the past, lake fishes were distributed to local populations with animals such as donkeys and mules and later with the use of motorcycles and tricycles. Currently, transport is with pickup trucks, which can reach even the most remote and mountainous village in the area. According to the fishers, the lake fishes play an important role in the local cuisine. For example, S. acarnanicus is cooked in the oven with tomato sauce and potatoes,

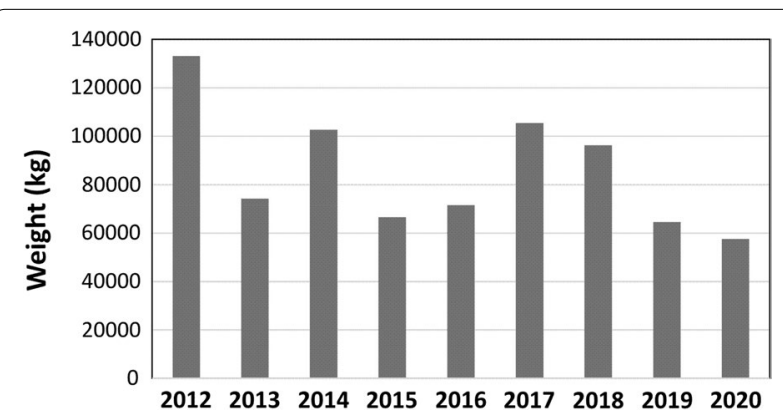

Fig. 2 The landings of Atherina boyeri $(\mathrm{kg})$ from Lake Trichonis for the period 2012-2020, according to the available data of the Department of Fisheries of the district green vegetables, or unripe plums, or it is grilled, or fried in local olive oil.

In response to the hypothetical question regarding a renewed demand for S. acarnanicus (e.g. for processing), all the fishers stated that they would not discard the catch, as long as the wholesale price of the fish could provide them with a profit margin.

\section{Responses from the lakeside population}

Of the 522 people surveyed, 234 were men $(44.8 \%)$ and 288 were women $(55.2 \%)$. The sample was divided into the following four age categories: $18-25,26-45,46-60$, and $>60$ years old. The largest percentage of respondents were in the age group 26-45 (54.5\%), while the age group $>60$ had the lowest participation in the sample (3.6\%).

When the responders were asked if they consume fish from Lake Trichonis, 379 people (72.61\%) answered positively, while 143 (27.39\%) responded negatively (Fig. 3 question 1). Men showed a greater preference for lake fishes compared with women ( $77.78 \%$ vs. $68.40 \%$, respectively), and this difference was statistically significant (Chi-square test, $p<0.05$ ) (Fig. 4).

With regard to the preference for specific fish, $A$. boyeri was top ranked (58.24\%), followed by Rutilus panosi (39.58\%), Silurus aristotelis (22.80\%), S. acarnanicus (15.71\%), and Luciobarbus albanicus (6.70\%). Among the respondents, $8.62 \%$ indicated that they preferred some other species, such as eel (Anguilla anguilla). Respondents had the opportunity to choose more than one answer (Fig. 3, question 2).

Most of the people who consume lake fishes stated that the frequency was once a month $(28.74 \%)$ or once a week $(25.10 \%)$, while $18.58 \%$ of respondents answered that they never eat fish from the lake. Only a few respondents $(0.96 \%)$ stated that they eat lake fish every day (Fig. 3, question 3). In answer to the question about how frequently they eat fish in general, $68.97 \%$ of the respondents answered that they consume fish once a week, while $1.15 \%$ indicated that they never eat fish (Fig. 3, question $4)$.

Among the reasons why they do not eat fish from the lake, $23.56 \%$ of the respondents stated that it is not easy to find them in the market and $19.16 \%$ that the fish are not so tasty, while $14.94 \%$ stated that it is difficult to prepare them for cooking (Fig. 3, question 5).

When asked if their elders ate more fish from the lake, a vast majority of the respondents (83.91\%) answered positively, while $13.79 \%$ replied negatively (Fig. 3, question 6). Respondents who answered positively were asked to choose which species of fish were consumed more frequently. The order of preference was $R$. panosi (67.43\%), A. boyeri (58.43\%), Silurus aristotelis 

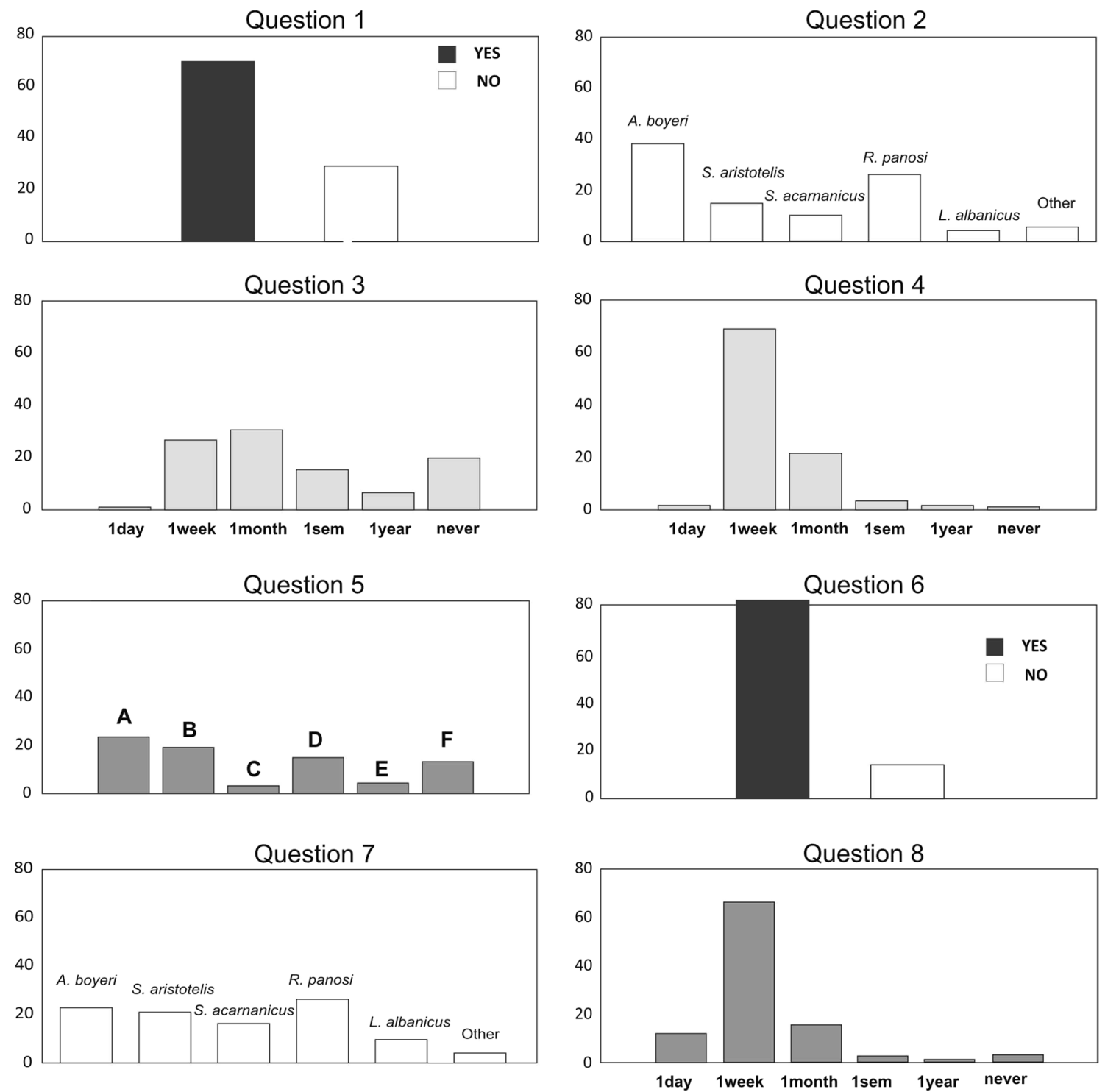

Fig. 3 The overall answers in each of the eight questions as \% percentage in the 522 answered questionnaires. 1: Do you consume fish from lake Trichonis? 2: If yes, which species? 3: How often do you consume fish from the lake? 4: How often do you consume fish in general? 5: If you don't consume fish from Lake Trichonis, which are the reasons for that? The A-F answers account for: $\mathbf{a} I$ can't find them in the market, $\mathbf{b}$ they are not so tasty, $\mathbf{c}$ it is difficult to cook them, $\mathbf{d}$ It is difficult to prepare them for cooking, e I prefer to eat frozen fish, $\mathbf{f}$ Other. $\mathbf{6}$ : In the past, were your parents and grandparents consuming more fish from lake Trichonis? 7: If yes, which species? 8: Those years, how often was the family consuming fish from the lake?

(53.83\%), Scardinius acarnanicus (41.57\%), L. albanicus (24.71\%), and other (10.34\%) (Fig. 3, question 7).

With regard to the question about the frequency of their family's past consumption of fish from the lake, $66.18 \%$ of the respondents answered that they ate fish once a week, while the $15.35 \%$ ate fish once a month. A notable number (12.03\%) stated that they consumed fish from the lake every day in the past (Fig. 3, question $8)$.
To detect any differences in the opinions of people in different age categories, an age-based analysis was carried out. The results showed that as age increases, the frequency of lake fish consumption decreases (Chisquare test, $p<0.05)$. Thus, in the age category $18-25$, fish from the lake were being consumed on a weekly basis $(42.3 \%)$, while in the age categories $26-45$ and 46-60, most answers indicated fish consumption on a monthly basis, with $29.06 \%$ and $43.75 \%$, respectively 


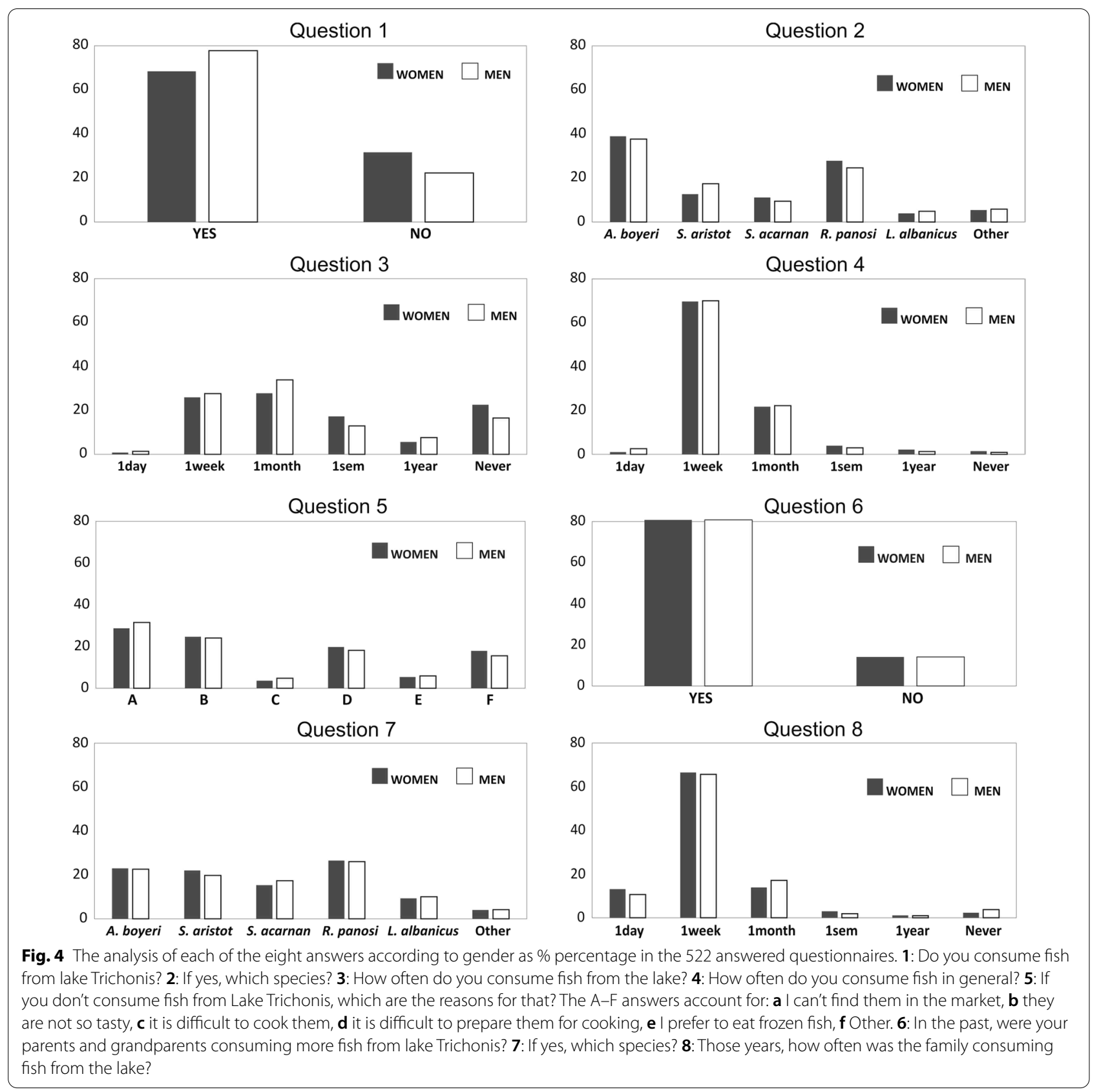

(Fig. 5). Moreover, in response to the question on the frequency of families' consumption of fish from the lake in the past, all age categories inclined towards once a week. However, some of the people in the 18-25 age category believed that consumption of fish from the lake was daily in the past. This opinion decreased gradually as age increased (18-25: 20.9\%, 26-45: 9.58\%, 46-60: 9.47\%, 60 : 6.25\%), with the "once a week" answer becoming more common with age (18-25: 10\%, 26-45: 14.94\%, 46-60: 20\%, >60: 31.25\%) (Fig. 6). These results were also statistically significant (Chi-square test, $p<0.05)$.

\section{Discussion}

\section{Background information}

Lake Trichonis is a freshwater ecosystem with certain peculiarities, including being among the few lakes worldwide that are inhabited by a marine fish. Atherina boyeri was naturally introduced from the sea into this ecosystem via river Acheloos and connecting canals, and once 


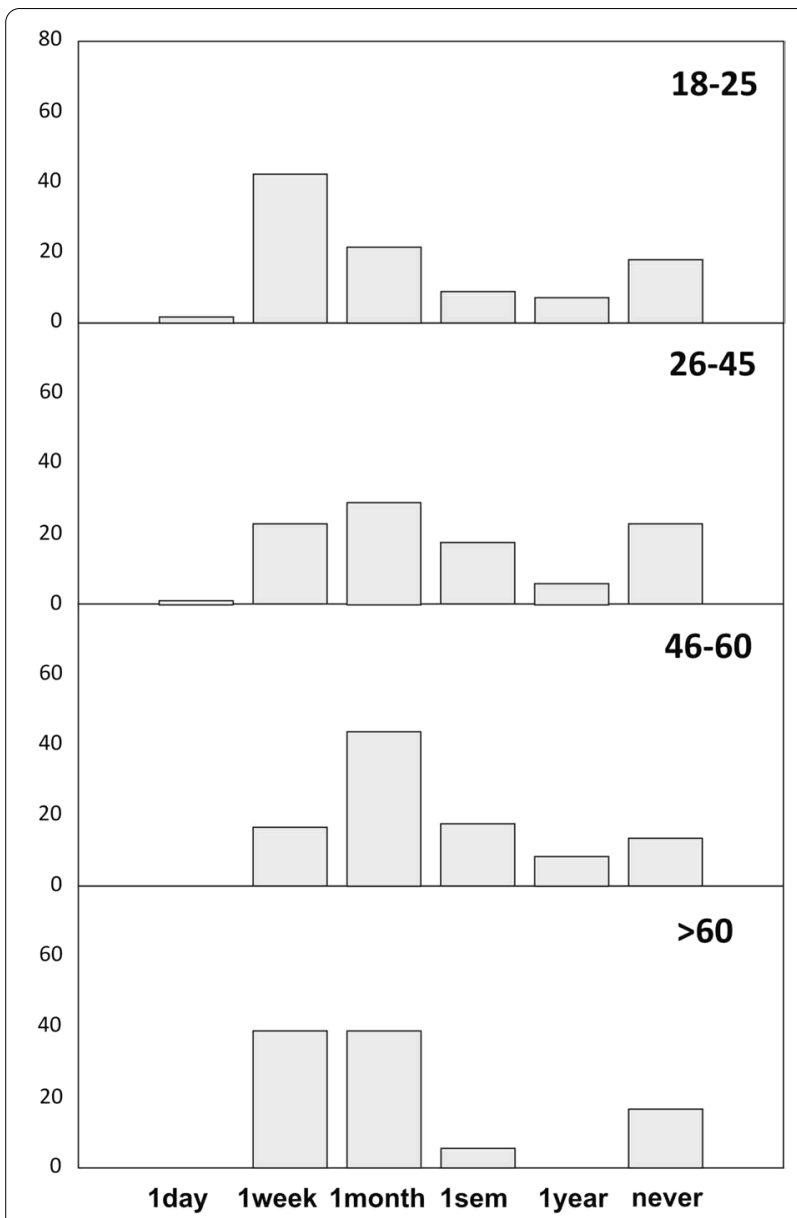

Fig. 5 Age-based analysis of the frequency of fish consumption from Lake Trichonis as \% percentage in the 522 answered questionnaires it acclimatized, it became the dominant species [16]. The large numbers of $A$. boyeri and the ease of cooking and consuming this small fish made it especially desirable to the local population. It also provided fishers with a good profit, leading to its commercial fishery. Until the early 1990s, the fishery of $A$. boyeri was conducted with bottom trawling. Afterwards, purse seine fishing with the use of light was introduced based on the scientific opinion [25]. The introduction of a fishery method used in marine environments is another peculiarity of this lake. As in the sea, purse seine lights attract this fish by attracting its prey, the zooplankton of the lake [3]. The zooplankton, which is dominated by copepod and cladoceran crustaceans [2,9], was found to respond to the light [10] and to concentrate close to it, acting as a cue to A. boyeri [12]. However, in this enclosed ecosystem, the use of fishery lights had some unexpected consequences. The planktivorous $A$. boyeri turned to prey heavily on the larvae of the native and endangered fish $E$. trichonis that were attracted to light $[13,14]$, while at the same time,

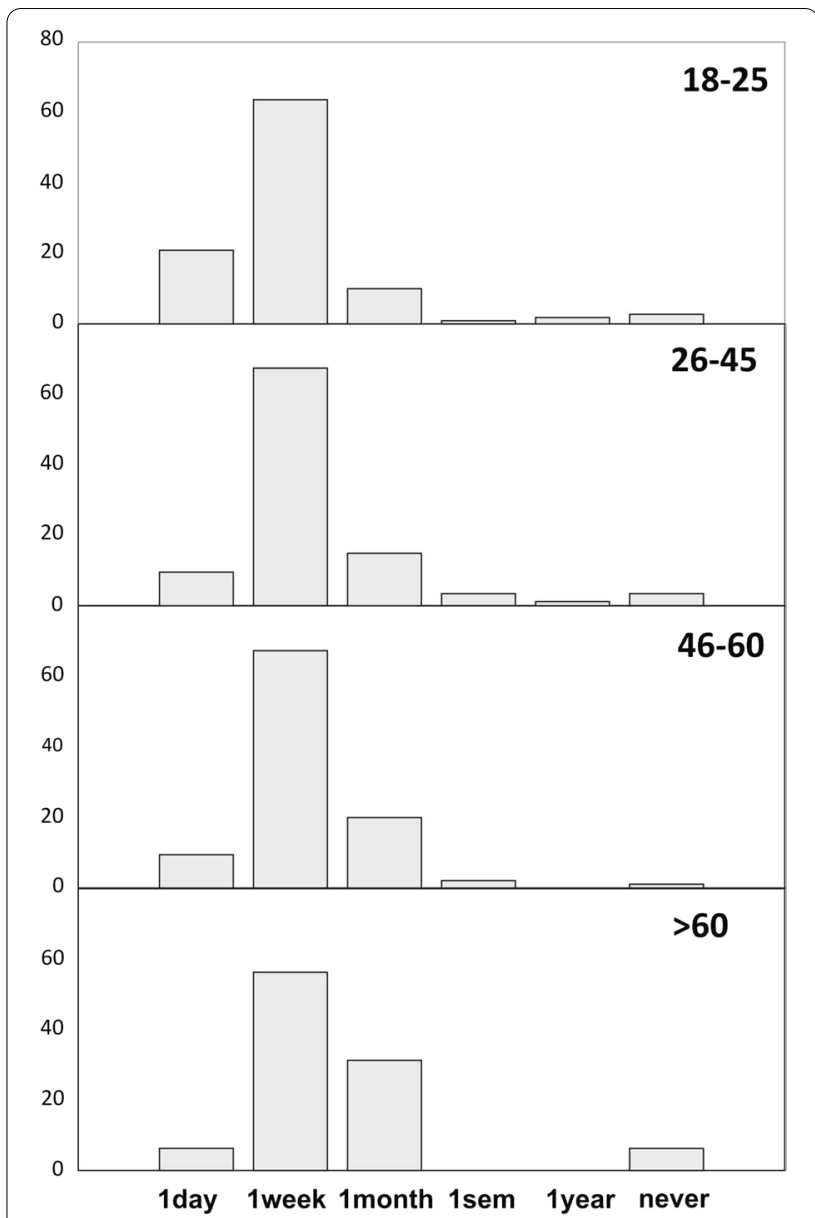

Fig. 6 Age-based analysis of the opinions about the frequency of fish consumption from Lake Trichonis in the past as \% percentage in the 522 answered questionnaires

it suffered the predatory behaviour of another fish, $S$. acarnanicus which had been found to be exclusively herbivorous [7] before the introduction of the fishery lights [25]. This species proved to be among the top predators in Lake Trichonis, consuming large numbers of $A$. boyeri, which is the commercially targeted species [25].

\section{The ecological perspective}

Another reason for the altered feeding preferences of S. acarnanicus could be improper on-board catch handling. When fishers retrieve their purse seines, the catch includes large numbers of $S$. acarnanicus in addition to the targeted A. boyeri; owing to low market demand, the live $S$. acarnanicus are returned to the lake. This practice of returning live fish to the lake, which has become more common in recent decades, may have inadvertently "taught" the $S$. acarnanicus population that it is safe to prey on A. boyeri in the presence of light at night as presented in Fig. 7 [25]. This hypothesis is supported by the 


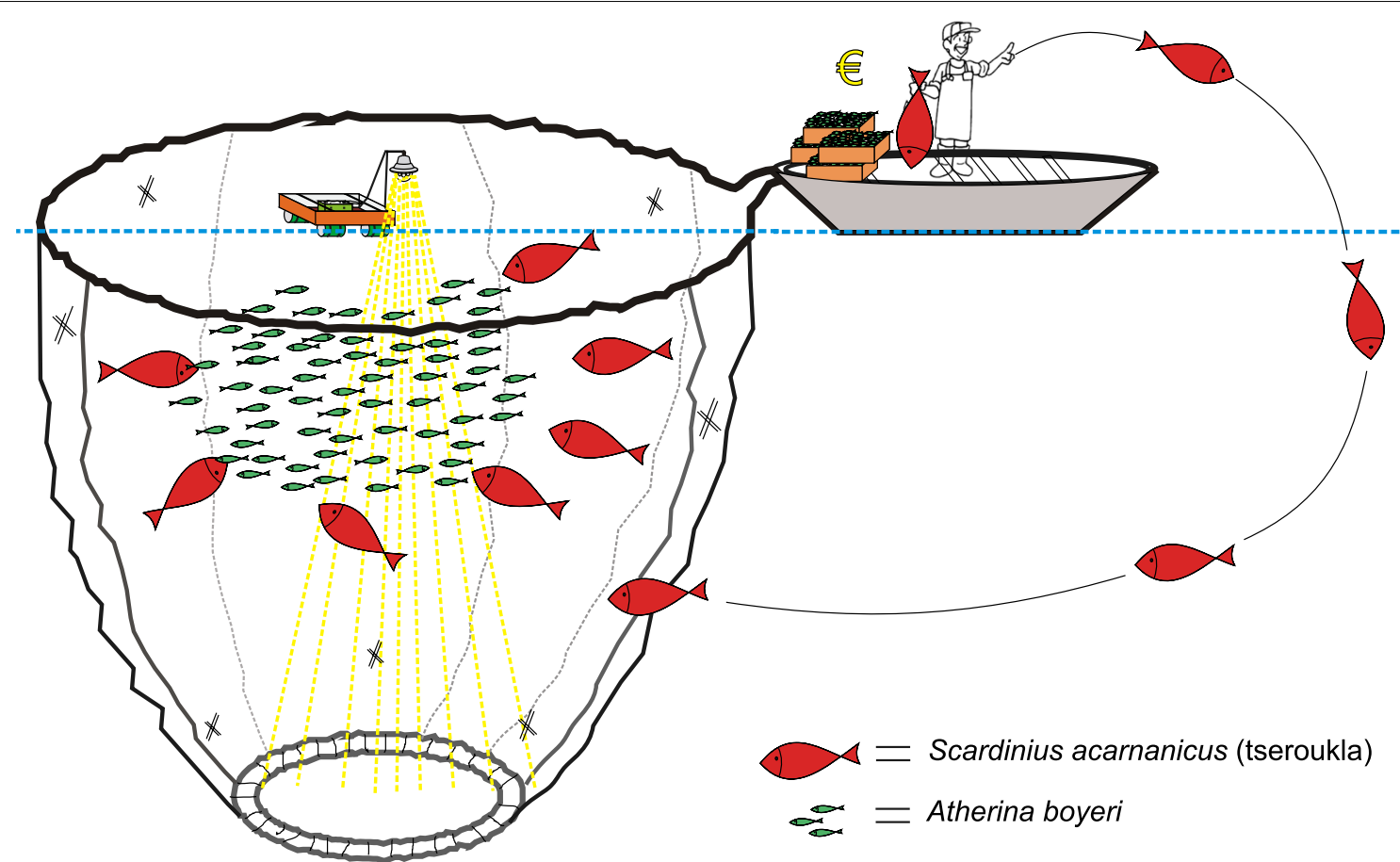

Fig. 7 Schematic representation of the "educational hypothesis" about the predation of Scardinius acarnanicus in Lake Trichonis. S. acarnanicus specimens caught in the purse seine nets are returned alive back to the lake and eventually learn that preying A. boyeri close to the fishing lights is not dangerous

fishers' observations that $S$. acarnanicus seem to not fear human activity anymore and, in contrast, follow the fishing boats. This "educational hypothesis" may be further supported given that $S$. acarnanicus can live for 10 years and that even the smaller members of its population can prey on A. boyeri [25]. Evidence of cultural transmission of foraging techniques in fish is not uncommon and has been proven experimentally $[29,30]$. There are several other examples of how human behaviour and practices may have conditioned animal behaviour [31], but to our best knowledge, there is no other similar case referring to the alteration of the feeding behaviour of a wild fish.

The combination of specific fishing methods (lightassisted fishing) and improper catch handling (returning live $S$. acarnanicus to the lake), promotes the increase in abundance of S. acarnanicus in contrast to the $A$. boyeri population, which is the target species in Lake Trichonis. Indirect proof of this population imbalance comes from the decrease in the $A$. boyeri landings, highlighting the necessity of examining the state of the lake's fish populations and proposing management actions to maintain the ecological balance, as well as the continuation of fishing. It must also be pointed out that in addition to the legal purse seine fishing boats, there are also many others that use fishing lights illegally, creating extra pressure on the stability of the lake's ecosystem.

\section{The effects of the dietary alteration}

The primary cause of the changes mentioned above seems to be the alteration of the dietary habits of the lakeside communities, with consequent reduction of consumption of fish from the lake, which started, as the fishers stated, in the 1980s. This diet alteration was apparent in the residents' answers, only when comparison with the past is attempted, since a significant proportion of the population still includes lake fish in their diet. Welcomme [27] reported that the landings of freshwater fishes in southern European countries, including Greece, decreased from 44,000 tons in 1986 to 17,415 tons in 2009. An outcome of the decreased consumption of freshwater fish is the depletion of workers in the inland fishing sector $[5,19,22]$. In the case of Lake Trichonis, this was reflected on the difficulty of finding lake fishes in the market due to their low demand. Atherina boyeri seems to be the most preferable fish not only because it is the most abundant in the lake [3], but also because it does not need any special preparation before cooking as the entire fish is eaten, and is easily consumed even by children, as it does not have any large bones. However, this species is rarely available in the local market due to the existence of such trade agreements which promote the catch in other major markets, such as in Athens and abroad. 
The diet alteration is probably a consequence of the homogenization of lifestyles and the erosion of the Mediterranean diet cultural heritage. These changes have been caused by factors such as shifts in intergenerational relationships and new interrelationships with the rest of the world via tourism and migration, which have in turn led to the Westernization of food consumption patterns in the Mediterranean area [15]. In the present study, the majority of respondents answered that they still consume fish from the lake, proving that there is a "familiarity" with the lake's fishes. Moreover, in this non touristic region of Greece, the local communities are more reclusive and conservative, which is probably another reason why old dietary habits are still maintained. A particularly encouraging fact is that younger people stated that they eat fish from the lake more frequently than the older, which may indicate a shift of the younger generation towards the traditional local diet.

Svanberg and Locker [24] claimed that the regression of many freshwater fish species as food is also due to the industrialization of marine fishing, leading to large quantities of fish reaching the inland market. The reduction of the lake fish in the diet of lakeside communities over the years in the studied area, could be also owed to several other reasons such as the weaker economic situation of the past, the possibly greater abundance of fish in the lake, the lack of other protein sources (e.g. meat), the lack of frozen products, or ready meals, and the disappearance of old recipes specifically for the lake fishes. Loukopoulos [18] devoted a large part of his research to the dietary habits of the inhabitants of Aetolia, which encompasses Lake Trichonis. According to this study, most of the fish in the lake were consumed during periods of fasting before major religious holidays, such as Christmas and Easter. Loukopoulos [18] also reported the ways in which each type of fish was cooked, for example, S. acarnanicus was boiled, baked in the oven, and fried. It is noteworthy that the specific dietary habits and recipes, some of which were also mentioned by the fishers in the interviews, come from ancient times and represent the history and the struggle of the inhabitants for survival. These recipes must be saved, preserved, and developed, as they represent an intangible cultural heritage.

\section{Conclusions}

The present study reveals that in the case of Lake Trichonis, a close relation may exist between the dietary preferences of the local population and the environmental status of the ecosystem. The present ecological instability could eventually lead to an increase in the population of $S$. acarnanicus as the top predator and to an inevitable decrease in the main catch of the lake (A. boyeri). Such changes would also affect the socioeconomic characteristics of the area. More specifically, the ecological instability could lead to the destruction of the fishing industry of the lake, which would inevitably lead to income loss, impoverishment, and immigration away from the area. Thus, at a local scale, the adoption of certain management measures is necessary.

- The adjustment of the fishing legislation to decrease the days of fishing, especially during the reproductive periods, would strengthen the threatened populations of A. boyeri and E. trichonis. Accordingly, given that fishing lights remain on for more than $8 \mathrm{~h}$ before the purse seining, a decrease in this time would reduce the predation impact on the populations of the above species. Both these actions would be expected to decrease the ecological instability through limiting the predatory behaviour among fishes.

- The establishment of a fishing association to manage the catches, in cooperation with scientific research and contribution, would lead to a better fishery management of the ichthyofauna of the lake.

- Through this association, fishers could be educated on proper catch handling, which would probably alter their custom of returning S. acarnanicus from their catch to the lake alive. However, their main concern would always be the disposal of these fishes in the most convenient way.

- Processing the excess S. acarnanicus and producing quality products of high nutritional and commercial value or/and creating new dietary products and recipes would be helpful. This approach could be combined with the promotion of ecotourism, agritourism, and food tourism, which would bring growth to the region, creating new jobs and opportunities in an area that is one of the poorest in the country.

Considering a broader ecological perspective, the present study demonstrates a paradigm of adapted evolution by a wild fish under the pressure of human activities that have led to specific dietary preferences and feeding behaviour. Finally, considering that many communities around the world live close to lakes and other freshwater ecosystems and utilize their food resources, and that changes in their diets seem to be inescapable, this investigation could motivate similar studies and concerns.

\footnotetext{
Acknowledgements

We thank the fishers who shared their knowledge with us; the Department of Fisheries of Aetoloakarnania for the landing data about Lake Trichonis; the Directorate of Primary Education of Aetoloakarnania, which helped us with the necessary permissions; and the teachers and the principals of the elementary schools in which the questionnaires were distributed.
} 


\section{Authors' contributions}

All authors contributed equally in the creation of the present article. All authors read and approved the final manuscript.

\section{Availability of data and materials}

All the data supporting the findings of this study are available within the article.

\section{Declarations}

\section{Competing interests}

The authors declare no competing interests.

\section{Author details}

${ }^{1}$ Department of Environmental Engineering, University of Patras, Agrinio, Greece. ${ }^{2}$ Department of Food Science and Technology, University of Patras, Agrinio, Greece.

Received: 13 June 2021 Accepted: 31 August 2021

Published online: 06 September 2021

\section{References}

1. Blakeway R, Jones G, Boekhoudt B. Controlling lionfishes (Pterois spp.) with consumption: survey data from Aruba demonstrate acceptance of non-native lionfishes on the menu and in seafood markets. Fish Manag Ecol. 2019;27:3.

2. Doulka E, Kehayias G. Spatial and temporal distribution of zooplankton in Lake Trichonis (Greece). J Nat Hist. 2008;42:5-8.

3. Doulka E, Kehayias G, Chalkia E, Leonardos I. Feeding strategies of Atherina boyeri (Risso, 1810) in a freshwater ecosystem. J Appl Ichthyol. 2013;29:1

4. Economou A, Daoulas C, Psarras T, Barbieri-Tseliki R. Freshwater larval fish from Lake Trichonis (Greece). J Fish Biol. 1994:45:17-35.

5. Ernst \& Young. EU intervention in inland fisheries "Studies linked to the implementation of the European Fisheries Fund." Brussels: European Commision; 2011.

6. Gabriel O, Lange K, Dahm E, Wandt T. Fish catching methods of the world 4th ed. Oxford: Blackwell Publishing; 2005.

7. Iliadou K. Feeding of Scardinius acarnanicus Stephanidis, 1939 (Pishes: Cyprinidae) from Lakes Lysimachia and Trichonis. Greece J Fish Biol. 1991;30:3.

8. Jew S, AbuMweis S, Jones P. Evolution of the human diet: Linking our ancestral diet to modern functional foods as a means of chronic disease prevention. J Med Food. 2009;12:5

9. Kehayias G, Michaloudi E, Bexi A. Aspects on the seasonal dynamics and the vertical distribution of the crustacean zooplankton community and the Dreissena polymorpha larvae in Lake Trichonis. Mediterr Mar Sci. 2004;5(1):19-27.

10. Kehayias $G$, Doulka E. A light trap for sampling Atherina boyeri larvae in Lake Trichonis (western Greece). J Freshw Ecol. 2007;22(3):533-4.

11. Kehayias G, Doulka E. Trophic state evolution of a large Mediterranean lake utilizing abiotic and biotic elements. J Environ Prot. 2014;5:1.

12. Kehayias G, Bouliopoulos D, Chiotis N, Koutra P. A photovoltaic-batteryLED lamp raft design for purse seine fishery: application in a large Mediterranean lake. Fish Res. 2016:177:18-23.

13. Kehayias G, Tzavali A, Gini M, Michopoulou E, Tsounis L. Fish predation in the proximity of purse seine fishing lights: the case of Atherina boyeri
(Actinopterygii: Atheriniformes: Atherinidae) in a Greek Lake. Acta Ichthyol Piscat. 2018;48:1.

14. Kehayias G, Tsounis L, Georgoula E. Fishery lights result in elevated predation of the endangered fish Economidichthys trichonis by Atherina boyeri in Lake Trichonis (Greece). Ecol Saf. 2018;12:116-27.

15. Lacirignola C, Capone R, Bilali H, Debs EP, Cardone G, Driouech N, Dernini S, Burlingame B, Gitz V, Maybeck A. Mediterranean food consumption patterns: diet, environment, society, economy and health. Rome: Food and Agriculture Organization of the United Nations; 2015.

16. Leonardos I. Ecology and exploitation pattern of a landlocked population of Sand Smelt, Atherina boyeri (Risso, 1810) in Trichonis Lake (western Greece). J Appl Ichthyol. 2001;17:6.

17. Li D, Prinyawiwatkul W, Tan Y, Luo Y, Hong H. Asian carp: a threat to American lakes, a feast on Chinese tables. Compr Rev Food Sci Food Saf. 2021;20:3.

18. Loukopoulos D. Aetolian settlements, utensils and food. Athens: Folklore archive publications; 1925.

19. Mitchell M, Vanberg J, Sipponen M. Commercial inland fishing in member countries of the European Inland Fisheries Advisory Commision (EIFAC): operational environments, property rights, regimes and socio-economic indicators. Rome: Food and Agriculture Organization of the United Nations; 2010.

20. Nunez M, Kuebbing S, Dimarco R, Simberloff D. Invasive species: to eat or not to eat, that is the question. Conserv Lett. 2012;5:334-41.

21. Odum E. Fundamentals of ecology. 3rd ed. Philadelphia: W.B. Saunders company; 1971.

22. Salz P, Baisman E, Smit J, de Vos B. Employment in the fisheries sector: current situation (FISH/2004/4). Final report. 2006.

23. Svanberg I, Locker A. Ethnoichthyology of freshwater fish in Europe: a review of vanishing traditional fisheries and their cultural significance in changing landscapes from the later medieval period with a focus on northern Europe. J Ethnobiol Ethnomed. 2020;17:6.

24. Svanberg I, Locker A. Caviar, soup and other dishes made of Eurasian ruffe, Gymnocephalus cernua (Linnaeus, 1758): forgotten foodstuff in central, north and west Europe and its possible revival. J Ethnic Foods. 2020;7:3.

25. Tsounis $L$, Kehayias $G$. Alteration of the feeding behaviour of an omnivorous fish, Scardinius acarnanicus (Actinopterygii: Cypriniformes: Cyprinidae), in the presence of fishing lights. Acta Ichthyol Piscat. 2021;51:2.

26. Varble S, Secchi S. Human consumption as an invasive species management strategy: a preliminary assessment of the marketing potential of invasive Asian carp in the US. Appetite. 2013;65:58-67.

27. Welcomme R. Review of the state of the world fishery resources: Inland Fisheries. Rome: Food and Agriculture Organization of the United Nations; 2011.

28. Westhoek $H$, Rood T, van den Berg M, Janse J, Nijdam D, Reudink M, Stehfest E. The protein puzzle. The Hague: PBL Netherlands Environmental Assessment Agency; 2011.

29. Whitten A. Cultural evolution in animals. Annu Rev Ecol Evol Syst. 2019;11:0.

30. Whitten A. The burgeoning reach of animal culture. Science. 2021. https://doi.org/10.1126/science.abe6514.

31. Wong B, Candolin U. Behavioural responses to changing environments. Behav Ecol. 2015;26:3.

\section{Publisher's Note}

Springer Nature remains neutral with regard to jurisdictional claims in published maps and institutional affiliations. 